\title{
The role of education in peacebuilding: an analysis of five change theories in Sierra Leone
}

Smith Ellison, C. (2012). The role of education in peacebuilding: an analysis of five change theories in Sierra Leone. COMPARE, 10.108. https://doi.org/10.1080/03057925.2012.734138

Link to publication record in Ulster University Research Portal

\section{Published in: \\ COMPARE}

Publication Status:

Published (in print/issue): 30/10/2012

DOI:

10.1080/03057925.2012.734138

\section{Document Version}

Publisher's PDF, also known as Version of record

\section{General rights}

Copyright for the publications made accessible via Ulster University's Research Portal is retained by the author(s) and / or other copyright owners and it is a condition of accessing these publications that users recognise and abide by the legal requirements associated with these rights.

\section{Take down policy}

The Research Portal is Ulster University's institutional repository that provides access to Ulster's research outputs. Every effort has been made to ensure that content in the Research Portal does not infringe any person's rights, or applicable UK laws. If you discover content in the Research Portal that you believe breaches copyright or violates any law, please contact pure-support@ulster.ac.uk. 


\section{The role of education in peacebuilding: an analysis of five change theories in Sierra Leone}

Christine Smith Ellison*

School of Education, University of Ulster, Coleraine, Northern Ireland, UK

This paper raises a number of critical questions regarding the contribution of education to peacebuilding. Despite recent calls for greater collaboration between the two fields, there is still a lack of clarity regarding the change theories through which education may contribute to peacebuilding processes. This paper outlines developments over the past decade in the field of education and conflict, before identifying five rationales for the ways in which education contributes to peacebuilding. The second half of the paper examines the translation of these rationales into practice. Sierra Leone is often regarded as a success story of UN peacebuilding and, 10 years post-agreement, offers the opportunity to examine a broad range of programming. Using data gathered during a two-week field study (17-28 January, 2011), the paper reflects on five education programmes that operated in Sierra Leone in the post-conflict period. Semi-structured interviews were held with project personnel and beneficiaries, educational officials, students and graduates, community leaders and UN personnel to assess views on the contribution of education to peacebuilding, the rationales informing projects and challenges to implementation. A number of critical questions are raised regarding the lessons learned by the international community, its tendency to pursue its own agendas and its commitment to conflict transformation through peacebuilding.

Keywords: conflict; education; peacebuilding; Sierra Leone

\section{Education, conflict and peacebuilding}

The role of education in conflict-affected countries has received increased attention over the past decade due to its significance for the achievement of the education-related Millennium Development Goals. A growing body of work has emerged on the subject, both within the academic field (Smith 2005; Paulson and Rappleye 2007; Novelli and Cardozo 2008) and from donors, including the World Bank (Buckland 2005), the

\footnotetext{
*Email: c.smithellison@ulster.ac.uk
} 
Department for International Development (Smith and Vaux 2003) and the Organisation for Economic Co-operation and Development (OECD) DAC Fragile States Group (Rose and Greeley 2006). An important study by Bush and Saltarelli (2000) highlighted the 'two faces' of education and its role in both fuelling and mitigating conflict. The report drew on a number of international examples to highlight the ways in which education has exacerbated intergroup hostility. These include the use of education as a weapon in cultural repression (the refusal to allow the Kurdish minority in Turkey to use their language in schools), the denial of education as a weapon of war (destruction of schools in Mozambique and the forced closure of Palestinian schools by Israel) and the manipulation of textbooks (negative ethnic stereotypes in Rwanda and depiction of Tamils as the historic enemies of the Sinhalese in Sri Lanka). Subsequent studies have discussed the multiple ways that schools systems might reproduce social and gender inequalities that may be a catalyst for war (Davies 2004). Donors have thus increasingly recognised the need to conduct conflict analyses prior to designing programming in order to ensure their support addresses the underlying causes of conflict rather than ignoring or even exacerbating them. While this tends to highlight negative aspects of education policy and programming, Smith (2011a) identifies a number of positive contributions education can make based on, 'the distinction by Galtung between negative peace (the absence of violence) and positive peace (structural changes that address social injustice)' (5). These include the role that access to education can play in addressing group inequalities, the importance of education sector reform in encouraging new forms of power relations and the potential for education to support transformation processes related to security sector reform, political institutions, economic regeneration and social development.

While the international community has demonstrated a commitment to peacebuilding, it has been slow to take on board the lessons regarding education's contribution to conflict transformation. In 2006, a new UN peacebuilding architecture was established including the Peacebuilding Commission (PBC), the Peacebuilding Support Office (PBSO) and the Peacebuilding Fund (PBF). In his 2009 report on peacebuilding in the immediate aftermath of conflict, UN Secretary-General Ban Ki-Moon places social services, including education, among the five recurrent priorities for peacebuilding in post-conflict transition. Other studies also highlight the importance of social policies such as education and healthcare in maintaining peace in post-conflict contexts (Collier and Hoeffler 2002). Nevertheless, to date social services, and in particular education, have not been prioritised as compared with interventions in the security sector and political processes. Since 2006, the PBF has received US\$ 347 million, and education-specific projects account for just $3 \%$ of the total funding provided (UNESCO 2011, 36). 


\section{Education's contribution to peacebuilding: the theory}

Attention is now beginning to be drawn to the importance of supporting education in the aftermath of conflict. The recent UNESCO Global Monitoring Report (2011) calls for an increased role for education in peacebuilding and, in particular, for the resources available through the UN PBF to be increased to between $\$ 500$ million and $\$ 1$ billion a year. It also specifically calls for the United Nations Children's Fund (UNICEF) and the United Nations Educational, Scientific and Cultural Organization (UNESCO) to play a more central role in integrating education into wider peacebuilding strategies of the Peacebuilding Commission. Whilst the report argues for early engagement and prioritization of education throughout all conflict phases, there is no critical analysis of the change theories through which this will contribute to peacebuilding. This section aims to contribute to clarification by identifying from the literature five roles for education in peacebuilding.

\section{Skills training provides routes other than violence}

Through disarmament and demobilization, the process is meant to remove weapons - and war itself - as a means of livelihood and, through the reintegration process, to replace these livelihoods with ones that contribute to stability, peace and growth. It is the reintegration phase of DDR programmes that link them directly to the peacebuilding process. (Paulson 2009, 836)

Disarmament, Demobilization, and Reintegration (DDR) - programmes aimed at dismantling armed factions and reintegrating former combatants into communities - is now an integral component of the "post-conflict reconstruction orthodoxy' (Muggah 2005, 242). This first rationale relates to the role of skills training, often implemented as part of DDR, and its contribution to peacebuilding. According to the rationale, it is thought disarmament and demobilization create short-term negative peace - or the absence of violence - whilst reintegration, provided through skills training and, crucially, the recreation of livelihoods, contributes to long-term social transformation towards an economically active and integrated population.

\section{Education protects children}

Quality education provides physical, psychosocial and cognitive protection. (UN 2009, 1)

A second argument for the way in which education may contribute to peacebuilding relates to arguments made by those working in the field of 'education in emergencies' (Brock and McCorriston 2008; Inter-Agency Network for Education in Emergencies [INEE] 2010). These are based not only on the 
fact that education is a human right, but also the idea that education offers children protection in the context of disaster. It is argued that schools are safe places that offer physical protection from danger and help to protect against exploitation and recruitment (INEE 2004; Nicolai 2009). They offer an opportunity for children to learn important skills for survival (James 2010), including landmine and HIV/AIDS awareness. Evidence also suggests that education may provide protection through opportunities for psychological, emotional and cognitive development (INEE 2004). Immediate response can therefore halt the destruction of social and human capital and lay a sustainable foundation for recovery, development and peace (INEE 2010).

\section{Education helps re-establish 'normality'}

Education can help children return to a sense of stability, normality and confidence. (INEE 2010, 2)

Formal education has a particular symbolic significance for many communities that helps to restore faith in the state. (James 2010,9)

A number of authors have argued for the role of education in helping children to return to a sense of stability, normality and confidence (UN 2009; INEE 2010). The OECD DAC (2007) Principles for good international engagement in fragile states emphasise the need to focus on state building as the central objective and the idea of using rapid reconstruction as a means of demonstrating quick peace dividends is an influential one within UN discourse (McCandless 2011). One quick way of delivering this message is through the construction of schools. Formal education has a particular symbolic significance for many communities that helps to restore faith in the state (INEE 2004; Denis and Fentiman 2007; Nicolai 2009; James 2010, 9). The school buildings themselves can also help establish key services for children and the community, such as feeding programmes and vaccinations (Boyden and Ryder 1996).

\section{Education helps make up lost ground}

Where the opportunity of education has been lost due to conflict, it is not just a loss to the individual, but a loss of social capital and the capacity of a society to recover from the conflict. (Smith 2010, 1)

Educational inclusion lowers motivation and raises opportunity costs for participating in armed conflict. (Dupuy 2008, 2)

Quality education encourages critical thinking and the analysis of choice, which ultimately makes people less likely to follow the lure of charismatic leaders into armed conflict. (Save the Children 2008, 13) 
A fourth rationale relates to the idea that in the wake of conflict, education can help a country make up lost ground. There are two strands to this rationale. As demonstrated in Smith's quote above, education is thought to play a vital role in helping a country recover from the effects of conflict. It is also thought to have a protective role against future violence. The economic opportunities theory of armed conflict posits that people fight due to a desire for economic gain or 'greed'. People want to fight because it is economically profitable and they are able to fight as the cost of their labour is cheap. Education can affect the chance of violence by raising the opportunity cost to individuals. As educated people have more to lose economically, it is argued they are less likely to risk death or imprisonment by taking part in war (Collier and Hoeffler 2002).

Others argue that whilst 'greed' may sustain war, the economic agenda literature does not tell us much about why conflicts start in the first place (Bøås and Dunn 2007, 37). Relative deprivation theory stresses that conflict is the result of a perceived discrepancy between what people believe they are entitled to and what they believe they are capable of attaining, given the means available to them (Gurr 1970). According to this theory, an inclusive education system may help redress perceived injustices or 'grievances'. Others argue that education can reduce the likelihood of violence by inculcating an ability to critically analyse information, leaving people less open to manipulation by rebel leaders (Save the Children 2008).

\section{Education contributes to social transformation}

Cultivating an 'infrastructure for peace' means that we are not merely interested in 'ending' something that is not desired. We are oriented toward the building of relationships that in their totality form new patterns, processes and structures. (Lederach 1997, 84-5)

The concept of peacebuilding originated in the field of peace studies in the work of Galtung (1975). Core concepts in his work include the distinction between negative peace (the absence of violence) and positive peace (the absence of structural violence and the conditions for war). Galtung argued that peacebuilding is distinct from peacemaking and peacekeeping and involves, 'addressing and removing the root causes of violence - the structural and (a later addition to his work) the cultural violence - that feed into and enable direct violence' (Smith et al. 2011, 13). He also placed importance on local ownership. Lederach $(1995,1997)$, another key scholar in the field, highlighted that peacebuilding is a dynamic and social process. A key concept in his work is conflict transformation, which signifies an ongoing process of changing relationships, behaviour, attitudes and structures from the negative to the positive. According to this rationale, education for peace- 
Table 1. Summary of rationales for the role of education in peacebuilding.

\begin{tabular}{|c|c|}
\hline Peacebuilding rationale & $\begin{array}{l}\text { The literature on the role of education in } \\
\text { peacebuilding }\end{array}$ \\
\hline $\begin{array}{l}\text { Skills training provides routes } \\
\text { other than violence }\end{array}$ & $\begin{array}{l}\text { Skills training can lead to employment and } \\
\text { therefore a personal investment in activities other } \\
\text { than violence. }\end{array}$ \\
\hline Education protects children & $\begin{array}{l}\text { Education offers protection from violence so early } \\
\text { response can halt the negative impacts and provide } \\
\text { a foundation for recovery. }\end{array}$ \\
\hline $\begin{array}{l}\text { Education helps re-establish } \\
\text { 'normality' }\end{array}$ & $\begin{array}{l}\text { Schooling can help return a sense of normalcy to } \\
\text { children's lives and restore faith in a state's ability } \\
\text { to provide services for its citizens. }\end{array}$ \\
\hline $\begin{array}{l}\text { Education helps make up lost } \\
\text { ground }\end{array}$ & $\begin{array}{l}\text { Educated citizens help a country recover from the } \\
\text { effects of violence. Education can also provide } \\
\text { protection against future violence by increasing the } \\
\text { individual opportunity cost of war, addressing } \\
\text { grievances through equality of access to education } \\
\text { and promoting critical thinking. }\end{array}$ \\
\hline $\begin{array}{l}\text { Education contributes to social } \\
\text { transformation }\end{array}$ & $\begin{array}{l}\text { Education's influence can extend beyond the } \\
\text { school to support broader transformation in the } \\
\text { security, political, social and economic sectors and } \\
\text { a change in relationships and behaviours from the } \\
\text { negative to the positive. }\end{array}$ \\
\hline
\end{tabular}

building goes beyond 'peace education' to contribute to broader social transformations. See Table 1 for a summary of rationales for the role of education in peacebuilding.

\section{Education and peacebuilding in Sierra Leone}

Highlighted internationally as a peacebuilding success, and 10 years postagreement, Sierra Leone offers the opportunity to examine education and peacebuilding in practice. It is a country where the complex interrelationships between education and conflict, the 'education/war interface' (Davies 2004), have been demonstrated in powerful and symbolic ways. The drivers of the decade-long conflict are contested and opinions are generally polarised between those who categorise it as a war for diamonds driven by greed and those who view it as a response by youth alienated by a society beset by inequalities, patronage and corruption. In particular, analyses have highlighted the role of education as a source of grievances. Sierra Leone inherited a highly elitist education system from its colonial past. Independence saw a rapid expansion in provision and under the state's first Prime Minister, Sir Milton Margai, access increased greatly, particularly outside Freetown. In the years leading up to the war, particularly under Siaka Stevens' rule from 1968 to 1985, the education system suffered a severe decline. The 'forgotten aspirants' of this collapsing and exclusionary system were dismayed at the unfulfilled 
promises of social mobility in a reality where patronage got you further than education. According to Richards (1996) it was 20-30 of these 'excluded intellectuals', inspired by radical pan-Africanism and Gaddafi's Green Book (Abdullah 1998), who made up the initial Revolutionary United Front (RUF) membership. They drew in youth, as explained by Richards (1996):

The insurgency was waged mainly by rural youth who cited lack of education and jobs, unjust land tenure systems that left them landless, abuses by traditional chiefs and exploitative marriage laws, as major grievances. (62)

Whilst diamonds undoubtedly sustained the violence, 'it is a mistake to interpret the war as a systematic assault on mineral resources with ultimately criminal - not political - motives' (Meyer 2007, 8). Whilst the RUF's brutal tactics quickly lost it support, the speed with which people, and particularly youth, took to action speaks to a generalised rejection of the existing system. The conflict that began in 1991 with an attack by a small number of RUF fighters on communities near the Liberian border (Richards 1996) finally came to an end with a Joint Declaration of End of War on 18 January, 2002. Between 50,000 and 75,000 people had been killed (Dougherty 2004) and more than half the population had been displaced (Women's Commission for Refugee Women and Children 2004). See Figure 1 for a timeline of the conflict.

Novelli's (2011) analysis of early post-conflict programming in Sierra Leone highlights, 'a shared understanding, by both national and international actors, of the primordial importance of security for development' (23). This 'trickle down' approach to peacebuilding sees security as the foundation upon which development can occur, with little attention given to education in the immediate post-conflict period. As one example, Sierra Leone was officially put on the agenda of the UN PBC in 2006 and offered a PBF country envelope of $\$ 35$ million in 2007. None of the initial projects were explicitly education-focused (Novelli 2011, 31).

This is not to say that education has not received attention, but simply that in terms of the broader peacebuilding effort its contribution has

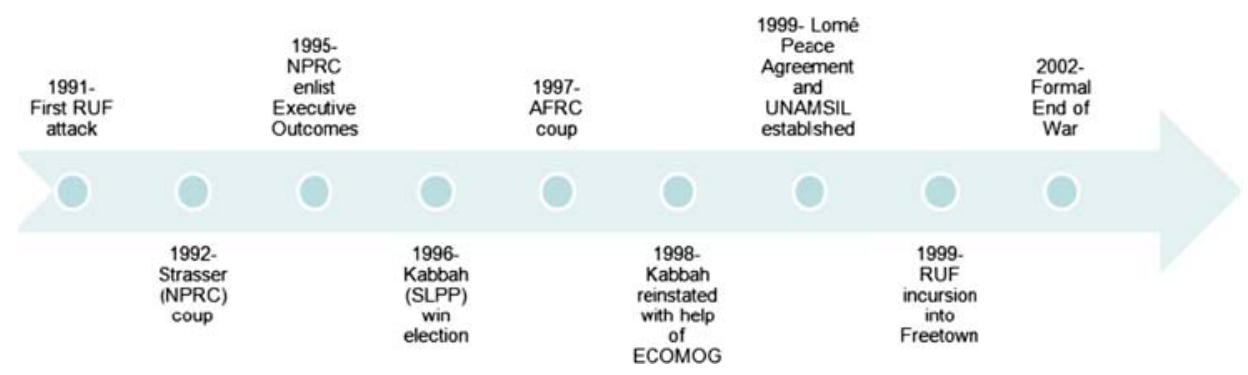

Figure 1. A timeline of the conflict in Sierra Leone. 
been seen as peripheral. In fact, since the end of the war in 2002 there has been a commitment to the education sector. The government introduced free primary education in 2001 and the Education Act 2004 enshrines the right to free basic education (primary plus three years of junior secondary school). It also pays the secondary school fees for girls in the northern and eastern regions where their enrolment is low. Sierra Leone was one of the first fragile states to secure Education For All-Fast Track Initiative (EFA-FTI) funding, an initiative designed to help countries achieve the Millennium Development Goal of Universal Primary Education. 'The long, drawn out, bureaucratic process of securing FTI funding' proved to be a 'frustrating experience for all' (Boak 2010, 39) and the US\$13.9 million eventually approved for the period 2007 to 2009 was a relatively small percentage $(5 \%)$ of the funding gap identified. However, the Education Sector Plan 2007-2015, developed as part of the process of applying for funding, is acknowledged by donors to be a well developed and sophisticated plan, which 'addresses the main issues affecting the education sector and the obstacles to its ongoing development' (Novelli 2011, 44).

In fact, donor funding in Sierra Leone has been seen as a success and is highlighted as such in UNESCO's (2011) global monitoring report. The report outlines a number of characteristics that were key to this success (33). Overall, the suggestion is that early engagement, sustained over a significant period of time, and with an early transition from humanitarian to development assistance through budget support, is an effective way to support peacebuilding through education. These are important lessons regarding the way in which aid to post-conflict education programmes should be delivered. However, the report appears to accept the suggestion that education is important for peacebuilding, without any critical analysis of how education might contribute to these processes. The following section aims to contribute to much-needed research in the area by examining five education programmes that operated in Sierra Leone in the post-conflict period. Programmes were selected on the basis that they demonstrate a variety of rationales for the way in which it is thought education contributes to peace. As there is a rationale to be made for implementing different programmes at different stages of a country's emergence from war, programmes were also selected to represent a range across time. Although the programmes are specific to Sierra Leone, there are wider lessons to be learned as similar approaches to education can be found in other post-conflict contexts. For example, DDR in Sierra Leone has informed processes in Liberia, Burundi and Haiti (Humphreys and Weinstein 2005). Similar Accelerated Learning Programmes (ALPs) can be found in Liberia and Uganda (Johannesen 2005, 8) and curriculum reform has been a part of post-conflict education policy in South Africa (Cross, Mungadi, and Rouhani 2010) and in Timor Leste (Shah 2012). 


\section{The practice: education programmes in Sierra Leone}

\section{Skills training component of DDR}

The first rationale relates to the role of skills training in providing ex-combatants with a means of livelihood that contributes to stability, peace and growth. The first DDR camp was opened in 1998, but the process was suspended after the 1999 RUF attacks on Freetown. This first phase was largely unsuccessful, with only 3000 ex-combatants registered for disarmament and demobilisation (Molloy 2004). A second phase began in 1999 following the signing of the Lomé Accord and 20,000 combatants took part. However, efforts were again disrupted by fighting in May 2000. In the third and final phase, close to 50,000 combatants disarmed, bringing the total to approximately 76,000 fighters (Molloy 2004).

Following disarmament and demobilisation in one of the 16 established centres, former combatants were offered the option of taking part in educational or skills training programmes. From a peacebuilding perspective, the critical issue is whether this leads to increased prospects for employment. While some may argue the benefits of an approach that contributes to negative peace by occupying the time of those 'who otherwise have very little to do' (Lyby 2001, 247), without recreation of livelihoods there is no transformative effect. It can even lead to the creation and fuelling of grievances as graduates feel the training has not lived up to its promises.

As can be seen from Figure 2, more than 12,000 ex-combatants opted for formal education and were placed in schools, colleges and universities. Their course fees were paid and they were given a living allowance for between one and three years. The United Nations Children's Fund also coordinated the Community Education Investment Programme, which waived school fees

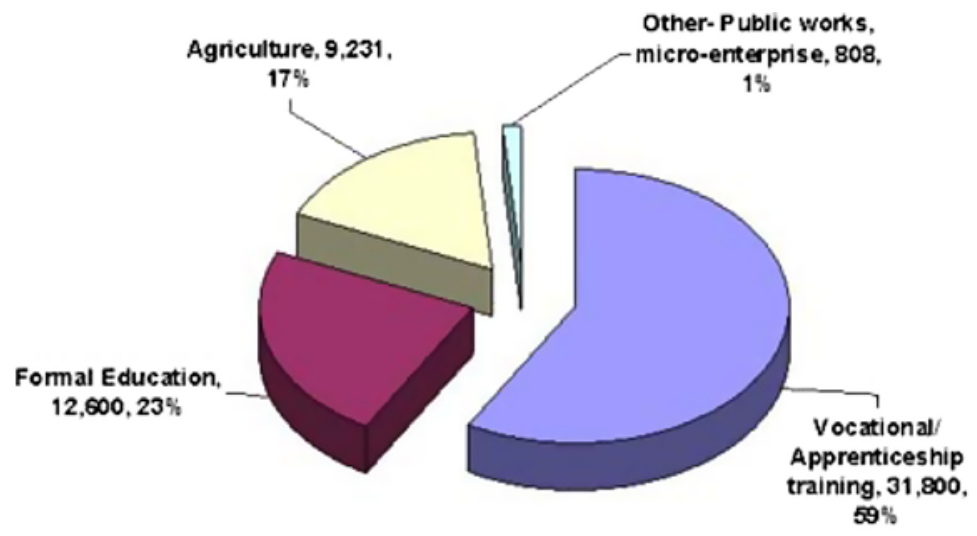

Figure 2. Ex-combatants that benefited from reintegration support.

Source: United Nations DDR Resource Centre, cited in Novelli $(2011,41)$. 
for former child soldiers and provided them with a uniform and school materials. Although the high number of ex-combatants that chose to enter into formal education is often seen as one of the successes of the process, this must be seen in a context where education has demonstrated an inability to fulfil its promises. In fact, Humphreys and Weinstein (2004) found that those who had more than a primary school education were slightly less likely to find employment than those who had not completed primary schooling.

The other option open to ex-combatants was to enrol on a skills training programme. These generally lasted for three months to a year and offered courses or apprenticeships in trades such as, "car repair, carpentry, computers, masonry, bicycle repair, building, plumbing, metalwork, road maintenance, tailoring, agriculture and, primarily for women, soap-making and tie-dying' (Paulson 2009, 840). A number of criticisms have been levelled at the training provided through DDR. The programmes were often too short to provide any meaningful acquisition of skills and the quality of the training varied greatly depending on which non-governmental organisation (NGO) it had been contracted out to. Some observers have also questioned the relevance of the skills provided, citing a severe lack of data on the needs of the labour market (Ginifer 2003). Given the constraints of Sierra Leone's economy, the employment prospects for even well-trained individuals are questionable.

More generally, these programmes assume an economically-driven root to the violence, either through criminal motives and greed for diamonds or simply boredom due to lack of employment. The responses therefore neglect resolving any social injustices or grievances that may have played a role in the lead up to the war. In fact, there has been a recognition that the DDR process itself can cause social divisions, such as community resentment over the 'special' treatment of ex-combatants. The two key providers of skills training as part of DDR in Sierra Leone, the National Committee on Disarmament, Demobilization and Reintegration (NCDDR) and the German Agency for Technical Cooperation (GTZ), have taken this issue into account to varying degrees. The NCDDR focused on community sensitisation, stressing the security benefits for society as a whole of keeping ex-combatants 'busy' in employment (Ginifer 2003). From the outset, however, GTZ extended its remit beyond ex-combatants to include, 'residents, IDPs, women, children and individuals who have contracted HIV/AIDS' (Ginifer 2003, 41) and has developed a holistic approach to reintegration. The youth resettlement and training component of its Employment Promotion Programme accomplishes a number of goals simultaneously. It identifies displaced youth, negotiates their return and provides resettlement support, counselling and health education, as well as agricultural training to encourage the development of farming skills that are an asset to the village (as well as contributing to the food security of the country). It also promotes reconciliation by requiring resettled and community members to work together throughout the whole process (Smith 2011b). 
Overall, the evidence indicates that where it is short-term, not well linked to the needs of the labour market and does not take adequate account of social processes, skills training as part of DDR not only has little impact in terms of increasing employment, but can also contribute to the creation of grievances. Rather than continuing to repeat the same processes in the hope of more successful outcomes, lessons should be learned from long-term responsive programming of agencies such as GTZ.

\section{Rapid Response Education Programme (RREP)}

A second rationale for the role of education in peacebuilding holds that education can provide physical, psychosocial and cognitive protection during emergencies. Immediate response can therefore halt the destruction of social and human capital and lay a sustainable foundation for recovery, development and peace (INEE 2010). One example of 'education in emergencies' in Sierra Leone was the Rapid Response Education Programme (RREP). Supported by the Ministry of Education, Youth and Sports, the Norwegian Refugee Centre (NRC) and UNICEF, RREP ran from 1999 to 2002 and was an emergency programme that aimed to teach or to review basic learning skills to children who had lost out due to war or displacement. The programme targeted those aged 10-14 years and included internally displaced children and those behind RUF lines. A total of 13,529 children participated in the programme. Overall, positive opinions were collected of RREP during fieldwork. However, it does raise a few issues. Firstly, the practicalities of the programme give support to those who question the view of schools as safe places, arguing that they may in fact be targets of attack (O'Malley 2010). Workshops were held in Lungi and Port Loko and rolled out in Kailahun, Kambia, Kono and Bo once the areas were deemed safe. However, RREP schools had to be moved on occasion due to insecurity, most notably in Port Loko where the second workshops focused only on teachers and children in the displacement camp.

There is also a question regarding the programme content. The increasing recognition of the role of education in providing protection following conflict means that many programmes now include psychosocial support, peace education and life skills training (James 2010). These additional subjects were included among the six modules of RREP:

- Literacy

- Numeracy

- Trauma healing

- Religious moral education

- Physical health education

- Peace and human rights education. 
There is evidence that good life-skills training can impact children's behaviour (Baxter and Bethke 2009) and in particular the HIV/AIDS section included in the Physical health education module was mentioned by teachers as very useful. However, evidence of the impact of psychosocial programmes is less clear. Many authors highlight the serious constraints to school-based psychosocial programmes. Boyden and Ryder (1996), for example, argue that class sizes are too big and that teachers are often undergoing their own psychological distress in these situations and it is not their role to run these programmes. Other studies present more positive findings. In a systematic review of the literature on interventions related to psychosocial well-being and mental health in low- and middle-income countries, Jordans et al. (2009) find that the majority of studies present some evidence of symptom reduction and/or increased protective factors. However, it also finds a gap between research, policy and practice. While the discourse promotes multi-levelled community-based approaches, culturally appropriate interventions and thorough evaluations of outcome, 'actual adherence to these principles is not often reported or lacks depth' (12). Furthermore, the scarcity of rigorous studies and the heavy reliance on anecdotal information mean the authors find the results 'far from convincing' (11). The trauma counselling component of RREP is not mentioned in any of the programme feedback sessions or evaluations and this does little to increase our understanding of the mechanisms by which it may contribute to peace. This creates the overall impression that psychosocial programmes are reproduced as part of a standard response without sufficient commitment to adaptation in response to criticism from the field.

\section{The Rehabilitation of Basic Education Project}

A third rationale argues that education can help restore a sense of normality in children's lives as well as faith in the state's ability to provide services. The Rehabilitation of Basic Education Project, known as the SABABU project, specifically made the connection between peacebuilding and school construction: 'it has the potential for making an important contribution towards the consolidation of peace, as re-establishing the school system plays a key role in returning to normalcy' (World Bank 2003, 4). It was initiated in 2002 as a collaboration between the Government of Sierra Leone (who provided $4 \%$ of funding), the World Bank (48\%) and the African Development Bank $(48 \%)$. The objective was to immediately re-establish education services and prepare the ground for building up the education sector. More specifically, the project consisted of two components: establishing basic operational levels in at least $50 \%$ of schools in target districts and enhancing the institutional capacity of the Ministry of Education, Science and Technology (MEST). In practice, the ambitions of the project were greatly scaled down. For example, only half of the 185 primary schools and less than $10 \%$ of teachers' housing 
identified as in need of refurbishment received attention (Republic of Sierra Leone/African Development Bank 2010, 4).

The aim of the project was a very valid one. The National School Survey Report in 2001 revealed that $35 \%$ of classrooms needed to be reconstructed and $52 \%$ needed repairs. The survey concluded that out of a total of 4854 school buildings, only 13\% were usable in their current condition (World Bank 2003, 4). In order to build on the work of existing projects, grants were provided to international and local NGOs already working in the area of service provision in the selected districts. These service providers (SPs) then contracted local builders to carry out the work, in theory maximising use of local labour, material and expertise (Bu-Buakei Jabbi 2007). Whilst this decentralised method may have some benefits, it does also present the issue of NGO/International NGOs wanting to 'brand' their school by placing their signs outside. This is understandable from the point of view of an organisation wishing to raise and show transparency of funds. However, if from a peacebuilding point of view the aim is to provide evidence of an active state, this clearly takes away from the desired effect by giving the impression that it is NGOs, rather than the state, who are reconstructing schools.

A further issue with the SABABU project was that it was continually open to charges of corruption. This is despite a number of measures taken to ensure transparency in the decision-making process. Potential schools were identified by an inspector and appraised by a technical team before being presented to a Project Steering Committee chaired by the Minister of Education. Once proposals were approved by the World Bank and the African Development Bank, funds were delivered to the SPs. However, the quality of the buildings that were constructed was often below standard and not 'commensurate with the funds provided'. 'Most of the structures are small and inadequately furnished. Some are and others will in the long term be inadequate to house the growing number of pupils' (Bu-Buakei Jabbi 2007, 12). Whilst it was originally intended that the project would conclude in 2005, it was far behind its timeline as SPs did not receive the money they had been promised. The project was finally closed in December 2009 having cost $\$ 42.1$ million. People are unlikely to have faith in a state that continues to demonstrate corruption. The issue of corruption also compounded the problem of sustainability. Having to upgrade construction work that is completed below standard places extra strain on a ministry that is already financially constrained.

More generally, the issue with these projects is that they assume a return to normality is a return to peace. However, the education system has been highlighted in conflict analyses as having played heavily into the creation of grievances in the years leading up to the outbreak of war. The programme initially allocated some money to capacity building, which presumably would have aimed at changes at a more systemic level. However, originally only $\$ 4$ million was allocated to this component, compared to the $\$ 18$ 
million allocated to reconstruction efforts, and in the end these efforts were negligible (World Bank 2003). Rebuilding the sector without these systemic changes may be simply recreating the pre-conditions for war.

\section{Complementary Rapid Education for Primary Schools (CREPS)}

The fourth rationale argues that education plays an important role in helping a country to recover from the effects of conflict. It may also provide protection against future violence by raising the opportunity cost of taking part in war, addressing perceived inequalities and inculcating an ability to critically analyse information. Complementary Rapid Education for Primary Schools (CREPS) was an ALP that aimed to increase access to schooling in Sierra Leone. The programme ran from 2001 until 2007 with support from UNICEF, MEST and the NRC (although the NRC discontinued support at the end of 2005). It was implemented in seven districts in the North and East provinces. The target group was children aged 10-16 years who had missed out on schooling or who had their schooling interrupted. It condensed six years of primary schooling into three years: class 1-2 of primary school, equivalent to CREPS level 1; class 2-4 (level 2 CREPS); and class 5-6 (level 3 CREPS).

As with many ALPs, CREPS faced the challenge that, at least initially, it existed as a parallel and competitive system to formal schooling. The programme met a lot of resistance from head teachers who saw it as competition in the context of government subsidies based on the number of pupils in each school. Indeed, particularly at the beginning of the programme there was a problem with under-age children enrolling illegally in CREPS. Many of these children were relatives of teachers who appeared to have a great deal of control over who was accepted on to the programme (Johannesen 2005).

The aim of the programme was that pupils would sit the National Primary School Exam and then continue into secondary school in the formal sector. In order to best prepare students for the exam, CREPS syllabus and manuals were prepared by MEST and UNICEF to ensure the contents and teaching were in harmony with what was being taught in the formal schooling system. A major difficulty was the low level of training of many of the teachers. Through the programme, CREPS teachers received only 10 days of training. From 2002, the NRC sought to tackle this issue by supporting non-qualified CREPS teachers to participate in a three-year Distance Education Programme that would allow them to obtain an officially recognized Teacher Certificate. However, the course materials had been developed before the level of teachers was known and, in practice, little use was made of them. The same was also true of the participatory teaching methods taught as part of the initial 10-day training, which was dropped in favour of a stronger focus on subject knowledge. Whilst in theory CREPS students followed a wide range of subjects, the low capacity of teachers meant that 
in practice it was limited to literacy and numeracy with a view to passing the exam. This limited view of education is unlikely to protect against violence in the ways outlined in the rationale.

It could, of course, be argued that it is not the role of an ALP such as CREPS to provide this broader type of education but rather to facilitate access into the formal system where this type of education can be taught. If CREPS as a short-term measure introduced pupils into the formal system at a sustainable rate then, arguably, changes could also be introduced to the education system to make that the case. However, CREPS ran from 2000 to 2005 , at which point programme documents reveal that it was expected the government would assume responsibility for the programme. It refused on the basis that it could not cope with the recurrent costs of the expanding education system. The Danish NGO Ibis took over the programme and are now phasing it out in 2011, 11 years after it began. From a peacebuilding perspective, increasing enrolment into a system that is already under pressure is likely to further fuel grievances that contributed to the pre-conditions of war. It is also where the rationale breaks down. Education may reduce the risk of violence. However, it will only raise the opportunity cost of violence if education succeeds in raising life chances. It will only protect against manipulation by rebel leaders if it successfully enables individuals to critically analyse. Inclusive education will only redress grievances if it is something people value.

Finally, while it is recognised that the priority of CREPS was a "catch up' programme for those aged between 10 and 16 years old, there is an argument that attention should also be given to the provision of these programmes for the generation of people, now adults, who missed out on an education. This is not to suggest that it would have been practical to extend the CREPS programme itself, but rather to highlight the gap. Adult education is an important and under-emphasised area of programming that has implications for not only participants' own future possibilities but also their ability to support their children's educational needs.

\section{Emerging Issues}

A fifth rationale holds that education's sphere of influence is not limited to schools but may also contribute to broader social transformations. Emerging Issues is a course which addresses a number of social issues thought important for the country's development. The course materials were developed by the teacher training institutions, UNICEF and MEST and are currently included in pre-service training courses, the distance education programme and in-service training for teachers. It is based around five areas of study:

- Principles of pedagogy

- Human rights 
- Civics and democracy

- Gender

- Health and environment.

The United Nations Children's Fund is also currently supporting the government in revising the primary school national curriculum and the debate regarding Emerging Issues largely concerns whether it should become a freestanding subject in the curriculum or whether an integrated approach should be taken. In the meantime, however, it has been found that although teachers are being trained to teach Emerging Issues, they are not quite aware of when to do it while teaching the usual subjects. A mapping analysis has therefore been undertaken of the syllabi and textbooks used in primary schools (primarily focused on Maths, English, Social sciences and Natural science) to identify the presence of Emerging Issues core areas. One of the key findings was that the coverage of gender was poor. The curriculum department and UNICEF ran a workshop and a further analysis was undertaken with a sole focus on gender. This involved examining textbooks in terms of the language used and the power dynamics demonstrated, as well as undertaking a numerical count of female and male characters. Classroom observation was also undertaken and marked against a gender-sensitive checklist.

The focus on gender inequalities is an important one. Women and girls were particularly victimised during the war. Thousands of girls were systematically abducted by rebel forces and forced into slave labour (Human Rights Watch 2003). Estimations are that anywhere from 215,000 to 257,000 women and girls in Sierra Leone were raped during the conflict (Amowitz et al. 2002). The entrenched patriarchal system also means that women and girls continue to suffer discrimination that hinders their reintegration and safety in the post-conflict society. In contrast to male counterparts, very few female combatants benefited from the demobilization and reintegration programmes set up for former child soldiers (McKay and Mazurana 2004).

Post-war reconstruction of the education sector can be seen as an opportunity to rectify discrimination against women, and international efforts are often aimed towards increasing female school enrolment in the aftermath of conflict (Maclure and Denov 2009). Again, this is an important goal. However, there is a large gap between expansion of girls' education and transformation of institutional frameworks and norms that may have contributed to or done little to alleviate systemic discrimination against girls and women. This is particularly the case in Sierra Leone, where the tenuous links between education and job markets do not bode well for the prospect of education as a force for gender equity. Furthermore, concerns, particularly from the security-focused organisations, surrounding the role unemployed young males played in the conflict and the idea that they, more than women, may provoke a climate of unrest, lead in practice to a bias in favour of male job placement: 
Given the interconnections between the scramble for work and the prevalence of patriarchal power relations, expansion of girls' access to education is unlikely to fundamentally transform traditional gender disparities that have long consigned women to low skilled, poorly remunerated work ... and the pervasiveness of women's economic dependency and vulnerability in Sierra Leone. (Maclure and Denov 2009, 617)

Importantly, Emerging Issues makes the laudable attempt to foster changes in values and attitudes. However, as critics have long pointed out, the idea of education as a catalyst for women's empowerment entails at the very least structural reforms in the organisation and administration of schools as well as in curricula and pedagogy. This is undoubtedly a more sensitive endeavour that requires long-term engagement and a move towards a more political realm for development organisations. The perhaps understandable hesitancy to engage in activities seen as overtly political is demonstrated in the way in which gender activities have come to focus on quantifiable targets such as the number of girls enrolled in school, the numerical count of female and male characters in textbooks, and marks against a gender-sensitive checklist. This depoliticises the very political activities and language of gender equality.

Overall, whilst gender equality is clearly important, its articulation through Emerging Issues does not seem to present a coherent theory of change aligned to the analysis of roots of the conflict. Firstly, there is an apparent clash of agendas between the security organisations' targeting of young males and the education agencies' focus on fostering change in values relating to female empowerment. Combined with a hesitancy from educationalists to engage in structural change and activities seen as overtly political, the potential for the transformation of gender relations is limited. Furthermore, conflict analyses have identified the roots of Sierra Leone's conflict as lying primarily in rural-urban inequalities and the disenfranchisement of youth from the political elite. The priority to gender would therefore seem to be derived from the international community agenda rather than arising from thorough conflict analysis of the factors contributing to this particular war.

\section{Conclusion}

This study has identified five rationales for the ways in which it is thought education may contribute to peace. An analysis of five post-accord education programmes working within these rationales in Sierra Leone has raised a number of criticisms regarding the international community's engagement in the area. Firstly, the analysis indicates that the international community is not learning lessons regarding the impact of programming. The inclusion of psychosocial interventions as part of the humanitarian response (as in RREP) suggests that these programmes are reproduced as part of a standard 
response without any learning. There are a number of critiques of this type of programme in the literature (Boyden and Ryder 1996) and the lack of evidence of impact has been identified elsewhere (James 2010). The lack of mention of RREP's trauma counselling in any of the feedback sessions or programme documents does little to increase our understanding of the mechanisms by which it may contribute to peace. The literature has also repeatedly demonstrated that DDR programmes that are not linked to the needs of the labour market and that do not pay adequate attention to the social aspect of reintegration do little in terms of peacebuilding and may even exacerbate and fuel grievances (Ginifer 2003; Paulson 2009). Such non-evidence-based programming leaves the international community open to charges of pursuing goals of distraction and pacification.

Secondly, Emerging Issues was designed as a course to tackle social issues deemed to be important to Sierra Leone and its development. However, the subsequent emphasis on gender would indicate that it is international organisation agendas, rather than local knowledge, leading programming. The analysis has also revealed a tendency to pursue Education For All (EFA) goals at arguably an unsustainable rate, evident in school construction efforts and catch-up programmes. A further issue is the organisational 'branding' of schools. This indicates that international organisations are pushing their own agendas rather than implementing programmes that are aimed towards restoring local confidence in government.

Finally, these charges, combined with the hesitancy to implement wider structural changes, lead us to question if there is really a genuine commitment to conflict transformation through peacebuilding. In fact, whilst the analysis of the rationales indicates that there is a role for education in contributing to peace, the analysis of the programmes suggests that in practice these education projects do not differ hugely from 'business as usual' development programmes. What is happening therefore is a rebranding of development education programmes as peacebuilding initiatives without thoughtful consideration of what that shift means in practice. The shift, however, is a significant one, with important consequences for programming. It involves putting conflict sensitivity at the heart of programming. Provision of skills training needs to be long-term and well linked to thorough analysis of the labour market. School construction and catch-up programmes need to include serious consideration of sustainability and equality issues. Crucially, the shift towards peacebuilding is also a move towards a more political realm. Skills training and analysis of labour market needs may involve taking decisions on what type of employment is best for a country and what its future economy should be based on. The UNESCO (2011) global monitoring report's call for a greater role for education in peacebuilding is therefore a hugely significant one. The decision to respond should be taken consciously, based on thoughtful reflection on what the shift means in terms of consequences for agency positioning, priorities and programming. 


\section{References}

Abdullah, I. 1998. Bush path to destruction: The origin and character of the Revolutionary United Front/Sierra Leone. Journal of Modern African Studies 36, no. 2: 203-35.

Amowitz, L.L., C. Reis, K.H. Lyons, B. Vann, B. Mansaray, A.M. AkinsulureSmith, L. Taylor, and V. Iacopino. 2002. Prevalence of war-related sexual violence and other human rights abuses among internally displaced persons in Sierra Leone. Journal of the American Medical Association 287, no. 4: 513-21.

Baxter, P., and L. Bethke. 2009.Alternative education: Filling the gap in emergency and post-conflict situations. UNESCO. http://unesdoc.unesco.org/images/0018/ 001849/184938e.pdf (accessed October 22, 2012).

Boak, E. 2010. Report on education financing, governance and accountability in Sierra Leone. London: Save the Children.

Bøås, M., and K.C. Dunn. 2007. African guerrilla politics: Raging against the machine? In African guerrillas: Raging against the machine, ed. M. Bøås and K.C. Dunn, 9-38. Boulder, CO: Lynne Rienner.

Boyden, J., and P. Ryder. 1996. Implementing the right to education in areas of armed conflict. Oxford: Department of International Development, University of Oxford.

Brock, C., and M. McCorriston. 2008. Towards the concept of education as a humanitarian response in the context of a UNESCO Chair/UNITWIN network. UNESCO. http://www.unesco.org.uk/uploads/TowardsEducationasaHumanitarian Response-June08.pdf (accessed October 22, 2012).

Bu-Buakei, J. 2007. The SABABU education project: A negative study of post-war reconstruction. Paper prepared for Tiri. TIRI. http://www.tiri.org/sites/www.tiri. org/files/documents/files/Sierra\%20Leone\%20SABABU\%20Education\%20Project $\% 20$ Case\%20Study.pdf (accessed October 22, 2012).

Buckland, P. 2005. Reshaping the future: Education and postconflict reconstruction. Washington, DC: The World Bank.

Bush, K., and D. Salterelli, eds. 2000. The two faces of education in ethnic conflict. Florence: UNICEF Innocenti Research Center.

Collier, P., and A. Hoeffler. 2002. On the incidence of civil war in Africa. Journal of Conflict Resolution 46, no. 1: 13-28.

Cross, M., R. Mungadi, and S. Rouhani. 2010. From policy to practice. Curriculum reform in South Africa. Comparative Education 38, no. 2: 171-87.

Davies, L. 2004. Education and conflict: Complexity and chaos. New York: Routledge.

Dennis, C., and A. Fentiman 2007. Alternative basic education in African countries emerging from conflict: Issues of policy, co-ordination and access. DFID. http:// www.dfid.gov.uk/Documents/publications/education-emerging-conflict67.pdf (accessed October 22, 2012).

Dougherty, B.K. 2004. Searching for answers: Sierra Leone's Truth and Reconciliation Commission. African Studies Quarterly 8, no. 1: 39-56.

Dupuy, K. 2008. Education for peace. Transforming armed conflict and building peace through education systems. Oslo: Save the Children, Norway.

Galtung, J. 1975. Three approaches to peace: Peacekeeping, peacemaking and peacebuilding. In Peace, war and defence: Essays in peace research, ed. J. Galtung, Vol. 2, 282-304. Copenhagen: Christian Ejlers.

Ginifer, J. 2003. Re-integration of ex-combatants. In Sierra Leone: Building the road to recovery, ed. M. Malan, S. Meek, T. Thusi, J. Ginifer, and P. Coker, 39-52. Pretoria: Institute for Security Studies Africa. 
Gurr, T.R. 1970. Why men rebel. Princeton, NJ: Princeton University Press.

Human Rights Watch. 2003. We'll kill you if you cry: Sexual violence in the Sierra Leone violence. Human Rights Watch. http://www.hrw.org/reports/200/sierraleone.

Humphreys, M., and J.M. Weinstein. 2004. What the fighters say: A survey of ex-combatants in Sierra Leone. New York: Columbia University.

Humphreys, M., and J.M. Weinstein. 2005. Disentangling the determinants of successful disarmament, demobilization and reintegration. Center for Global Development Working Paper No. 69.

Inter-Agency Network for Education in Emergencies (INEE). 2010. Minimum standards for education: Preparedness, response and recovery. New York: Author. http://toolkit.ineesite.org/toolkit/Toolkit.php?PostID $=1012$

INEE. 2004. Minimum standards for education in emergencies: Chronic crises and early reconstruction. Paris: INEE. http://toolkit.ineesite.org/toolkit/Toolkit.php? PostID=1012 (accessed October 22, 2012).

James, C. 2010. Supporting quality education for conflict affected children and young people. Report prepared for Comic Relief.

Johannesen, E.M. 2005. Fast track to completion: The Complementary Rapid Education for Primary Schools (CREPS) and the Distance Education Programme (DEP) in Sierra Leone. Norwegian Refugee Council evaluation report. Oslo: Educare, Norwegian Refugee Council.

Jordans, M., W. Tol, I. Komproe, and J. de Jong. 2009. Systematic review of evidence and treatment approaches: Psychosocial and mental health care for children in war. Child and Adolescent Mental Health 14, no. 1: 2-14.

Lederach, J.P. 1995. Conflict transformation in protracted internal conflicts: The case for a comprehensive framework. In Conflict transformation, ed. K. Rupesinghe, 201-22. New York: St. Martin's Press.

Lederach, J.P. 1997. Building peace. Sustainable reconciliation in divided societies. Washington, DC: US Institute of Peace Press.

Lyby, E. 2001. Vocational training for refugees: A case study from Tanzania. In Learning for a future: Refugee education in developing countries, ed. J. Crisp, C. Talbot, and D.B. Cipollone, 217-58. Paris: UNHCR's Evaluation and Policy Analysis Unit.

Maclure, R., and M. Denov. 2009. Reconstruction versus transformation: Post-war education and the struggle for gender equity in Sierra Leone. International Journal of Educational Development 29, no. 6: 612-20.

McCandless, E. 2011. Peace dividends and beyond: Contributions of administrative and social services to peacebuilding. New York: United Nations Thematic Review for the Peacebuilding Support Office.

McKay, S., and D. Mazurana. 2004. Where are the girls? Girls in fighting forces in northern Uganda, Sierra Leone and Mozambique: Their lives during and after war. Montreal: Rights and Democracy.

Meyer, S. 2007. Sierra Leone: Reconstructing a patrimonial state. FRIDE. http://www. fride.org/publication/226/sierra-leone:-reconstructing-a-patrimonial-state (accessed October 22, 2012).

Molloy, D. 2004. The DDR process in Sierra Leone: An overview and lessons learned. Freetown: UNAMSIL.

Muggah, R. 2005. No magic bullet: A critical perspective on Disarmament, Demobilization and Reintegration (DDR) and weapons reduction in post-conflict contexts. Round Table 94, no. 379: 239-52.

Nicolai, S. 2009. Opportunities for change: Education innovation and reform during and after conflict. Paris: IIEP/UNESCO. 
Novelli, M. 2011. The role of education in peacebuilding: Case study - Sierra Leone. Report prepared for UNICEF. UNICEF. http://www.educationandtransition.org/ wp-content/uploads/2012/01/EEPCT_Peacebuilding_CaseStudy_SierraLeone.pdf (accessed October 22, 2012).

Novelli, M., and M.L. Cardozo. 2008. Conflict, education and the global south: New critical directions. International Journal of Educational Development 28, no. 4: 473-88.

O'Malley, B. 2010. Education under attack. UNESCO. http://unesdoc.unesco.org/ images/0018/001868/186809e.pdf (accessed October 22, 2012).

OECD-DAC (Organisation for Economic Co-operation and Development DAC Fragile States Group). 2007. Principles for good international engagement in fragile states and situations. OECD. http://www.oecd.org/document/12/0,3343, en_2649_33693550_42113676_1_1_1_1,00.html.

Paulson, J. 2009. TVET and community re-integration in Sierra Leone's DDR process. In International handbook of education for the changing world of work: Bridging academic and vocational learning, ed. R. Maclean, 835-47. Dordrecht: Springer.

Paulson, J., and J. Rappleye. 2007. Bridging the theory-policy gap? A review of three recent publications in 'education and conflict'. International Journal of Educational Development 27, no. 3: 340-7.

Republic of Sierra Leone/African Development Bank. 2010. Aide memoire of the rehabilitation of basic and non-formal education and vocational skills training project (Education III Project). Project Completion Report.

Richards, P. 1996. Fighting for the rain forest: War, youth and resources in Sierra Leone. Oxford: James Currey.

Rose, P., and M. Greeley. 2006. Education in fragile states: Capturing lessons and identifying good practice. Report prepared for DAC Fragile States Group, Service Delivery Workstream. http://toolkit.ineesite.org/toolkit/INEEcms/uploads/ 1096/Educ_Fragile_States_Capturing_Lessons.PDF.

Save the Child ren. 2008. Where peace begins: Education's role in conflict prevention and peacebuilding. Save the Children. http://www.savethechildren.org.uk/ resources/online-library/where-peace-begins (accessed October 22, 2012).

Shah, R. 2012. Goodbye conflict, hello development? Curriculum reform in TimorLeste. International Journal of Educational Development 32, no. 1: 31-8.

Smith, A. 2005. Education in the twenty-first century: Conflict, reconstruction and reconciliation. Compare 35, no. 4: 373-91.

Smith, A. 2010. The influence of education on conflict and peacebuilding. Background paper prepared for Education for All Global Monitoring Report 2011.

Smith, A. 2011a. Education and peacebuilding: From 'conflict analysis' to 'conflict transformation'? Essay prepared for FriEnt. UNESCO. http://blogs.ulster.ac.uk/ unesco/files/2011/09/FriEnt_Essay_series_Smith.pdf (accessed October 22, 2012).

Smith, A. 2011b. Promoting education in countries affected by fragility and/or conflict: The case of Sierra Leone. Report prepared for GIZ.

Smith, A., E. McCandless, J. Paulson, and W. Wheaton. 2011. The role of education in peacebuilding: Literature review. Report prepared for UNICEF. Back on Track. http://www.educationandtransition.org/wp-content/uploads/2012/01/EEPCT_Peacebuilding_LiteratureReview.pdf (accessed October 22, 2012).

Smith, A., and T. Vaux. 2003. Education, conflict, and international development. London: Department of International Development.

United Nations. 2009. Background note for the UN General Assembly: Education in emergencies. United Nations. http:/www.un.org/ga/president/63/letters/background.pdf (accessed October 22, 2012). 
UNESCO-EFA. 2011. The hidden crisis: Armed conflict and education. Paris: UNESCO-EFA Global Monitoring Report.

Women's Commission for Refugee Women and Children. 2004. Global survey of education in emergencies. New York: Women's Commission for Refugee Women and Children.

World Bank. 2003. Project appraisal document on a proposed grant in the amount of SDR 15.1 million (US \$20.0 million) to the Republic of Sierra Leone for a 'Rehabilitation of Basic Education' Human Development II, Country Department 10, African Regional Office. http://wwwwds.worldbank.org/external/ default/WDSContentServer/WDSP/IB/2003/02/22/000094946_03021304094462/ Rendered/PDF/multi0page.pdf. 